\title{
Assessment of Microbiological Load and Safety of Selected Pre-Cut Fruits and Vegetables Sold at Two Major Markets in Accra-Ghana
}

\author{
Wiafe-Kwagyan $\mathbf{M}^{1 *}$, Dzifa $\mathbf{A J}^{\mathbf{1}}$ and Mensah $\mathbf{G I}^{\mathbf{2}}$ \\ ${ }^{1}$ Department of Plant and Environmental Biology, University of Ghana, Ghana \\ ${ }^{2}$ Noguchi Memorial Institute of Medical Research, University of Ghana, Ghana \\ *Corresponding Author: Wiafe-Kwagyan M, Department of Plant and Environmental Biology, University of Ghana, Ghana.
}

Received: September 04, 2019; Published: October 11, 2019

DOI: $10.31080 /$ ASNH.2019.03.0499

\begin{abstract}
Fruits and vegetables contain nutrients that are beneficial to human health. Consumption of fruits and vegetables in Ghana has always been high. In recent times, some fruits and vegetables sold to consumers in the country are pre-cut and packaged by vendors. However, the process of cutting and packaging of such fruits and vegetables may introduce some microorganisms detrimental to human health. The aim of this study was to investigate microflora on commonly consumed fruits (mango, pawpaw) and vegetables (okra and cocoyam leaves). These were sampled from two major markets Madina, and Makola at three different times for each study area. Violet Red Bile Agar (VRBA) and Plate Count Agar (PCA) media were used to enumerate coliform and total viable bacteria count respectively. Bacteria colonies were further identified using the Analytical Profile Index 20E. Cooke's and DRBC media were used for estimating the mycoflora population and diversity. The microbial population recorded on all samples ranged from 3.00logcfu/g to $5.48 \mathrm{log} \mathrm{cfu} / \mathrm{g}$. Makola market recorded the highest microbial load (3.74 log cfu/g to 5.48logcfu/g), followed by Madina market (3.00 $\log \mathrm{cfu} / \mathrm{g}$ to $5.48 \mathrm{log} \mathrm{cfu} / \mathrm{g}$.). The dominant bacteria species was Klebsiella pneumoniae, followed by Enterobacter (E. sakazakii, E. cloacae), Staphylococcus sp., Chryseomonas luteola. Yeast and Rhodotorula species predominated other fungi followed by Aspergillus (A. fumigatus, A. flavus, A. niger, A. candidus, A. parasiticus, A. oryzae and A. terreus), Streptomyces sp., Penicillum (P. expansum, P. digitatum, P. glabrum, P. verucosum, P. funiculosum), Mycelium sterillium, Rhizopus (R. oryzae, R. stolonifer), Fusarium oxysporium, Cladosporium (C. herbarum, C. macrocarpum) and Geotrichum candidum. Practical and health implications of their presence on precut fruits and vegetables are discussed.
\end{abstract}

Keywords: Fruits; Vegetables; Madina And Makola Markets; Microflora Population And Diversity

\section{Introduction}

Fruits are defined as the edible parts of plants that contain the seeds and pulpy surrounding tissue; have a sweet or tart taste; generally consumed as breakfast beverages, breakfast and lunch side-dishes, snacks or desserts [1]. Vegetables on the other hand are defined as edible plant parts including stems and stalks, roots, tubers, bulbs, leaves, flowers and fruits; and usually include seaweed and sweet corn; may or may not include pulses or mush- rooms which are generally consumed raw or cooked with a main dish, in a mixed dish, as an appetizer or in a salad [1]. Unprocessed (raw) fruits and vegetables are known to contain certain essential components such as carbohydrates, proteins, vitamins and minerals which are of vital importance to the health of humans [2]. In most countries, people consume raw vegetables and fruits because of the health benefits such as their ability to prevent diseases such as cancer, diabetes, cardiovascular diseases and stroke [3]. 
In addition to the health benefits to consumers, fruits and vegetables have economic benefit by providing employment for most women in developing countries. However, fruits and vegetables can harbour relatively high numbers of microorganisms at harvest because of their contact with the soil during growth. These microorganisms are normally nonpathogenic, epiphytic microflora but during production on the farm and all stages of product handling from harvest to point of sale, the produce may be contaminated with pathogens Beuchat; Beuchat and Ryu [4]. Fruits and vegetables are also exposed to contamination by microorganisms through direct contact with dust, water and by handling at harvest or during postharvest processing. In Ghana, fruits and vegetables are sometimes cultivated in areas with the presence of potentially harmful microbes like sewage, sludge, animal feces, and toxic weeds which can lead to the contamination during growth, harvesting and storage [5].

Furthermore, in developing and middle-income countries where unemployment is high most food vendors and hawkers sell fruits and vegetables without any strict supervision on how these fruits and vegetables are handled before they are sold to consumers. there is the need to ascertain the microbiological quality and the possible route cause of contamination to determine the safety of these fruits and vegetables. This is because, foodborne illness outbreaks are usually linked to meat, fish and milk products while neglecting the impact of fruits and vegetables contamination on human health. It is estimated that foodborne illnesses and waterborne illnesses together cause over 2 million annual deaths worldwide [6] with Ghana alone recording to about 65,000 of these deaths [7]. Foodborne illnesses do not only cause problems to the health of individuals but also cause major economic losses. In Ghana alone, an amount of 65,000 USD is spent annually in the control of foodborne illnesses [7]. Further to, in 1998 the FDA published the Guide to Minimize Microbial Food Safety Hazards for Fresh Fruits and Vegetables, recommending GAPs that growers, packers, and shippers implement to address the common microbiological hazards that may be associated with their operations FDA, 1998 [8].

Pre-cut fruits and vegetables are defined as fruits and vegetables that have been freshly cut open, sliced into pieces, peeled and packaged while still maintaining its freshness and offered to consumers for consumption at various retail outlets [9]. The World Health Organization (WHO), Food and Agriculture Organization (FAO) of the United Nations, and the World Cancer Research Fund (WCRF) recommended $400 \mathrm{~g}$ to $600 \mathrm{~g}$ daily consumptions of fruits and vegetables [10].

The aim of this study was to assess the microbiological quality and safety and the possible route of contamination on selected precut fruits and vegetables sampled from three markets within the Accra metropolis of Ghana.

\section{Materials and Methods}

Sample collection

Thirty (30) samples were collected randomly from two different markets (Madina and Makola markets) within the Accra Metropolis. The samples included pre-cut- mango, pawpaw, cocoyam leaves and okra. After collection, they were kept in a cold ice box and were immediately transported to the laboratory for microbial analysis. Sampling was repeated every 3 weeks for two months.

\section{Microbial enumeration}

Bacteriological analysis

One percent (1\%) peptone water was used for serial dilution preparations. Bacteriological count was done with the Plate Count Agar (PCA) (Biochemika 70152, Germany) to determine the total mesophilic aerobic bacteria whereas Violet Red Bile Glucose agar (Oxoid) was used for enumeration of coliform. All bacteriological media were prepared according to the manufacturers' instructions.

Pure cultures of the isolated bacteria were first Gram stained to differentiate between Gram negative and positive bacteria. The coagulase and catalase tests were to differentiate between Staphylococcus sp. and Streptococcus sp. Gram negative bacteria (e.g. Enterobacteriaceae) were identified and differentiated using the Analytical Profile Index 20E (API 20E). Isolates were further confirmed by Matrix-Assisted Laser desorption/ionization time of flight (MALDI - TOP - MS) Mass Spectrometry method as prescribed by (Bruker, 2014).

\section{Mycological analysis}

It was done according to the method described by ISO [11]. Fungi resident in the pre-cut fruits and vegetables were determined as prescribed using the decimal serial dilution technique up to $1: 10^{3}$. 
$1 \mathrm{ml}$ aliquots of the serially diluted samples were placed in either $20 \mathrm{ml}$ of Dichloran Rose Bengal Chloramphenicol agar (DRBC, CM 727) and Cooke's formulated media for fungal count. The plates were incubated at $28 \pm 2^{\circ} \mathrm{C}$ for 7 days.

Identification of mycoflora

Fungi isolated were identified by their cultural, colour morphological characteristics (microscopic and macroscopic) according Barnett and Hunter (2006); Samson and Reenen-Hoekstra (1988); Von-Arx (1970); George and Harold (1960) as well as other relevant identification manuals.

\section{Analysis of aero microflora from the market sites}

Petri plates containing respective media (i.e. PDA, Cooke's, DRBC, PCA, Nutrient agar and MacConkey) were exposed for 5 $\mathrm{min}$. The bacterial culture plates were incubated at $37^{\circ} \mathrm{C}$ for 2 days while fungal culture plates were incubated at $28^{\circ} \mathrm{C}$ for 7 days. To obtain pure cultures nutrient agar (NA) and potato dextrose agar (PDA) were used for the isolation of bacterial and fungal isolates respectively.

\section{Results}

Estimation and isolation of bacteria population on pre-cut fruits (mango and pawpaw) and vegetables (okra and cocoyam leaves) from madina and makola markets in accra-ghana

Generally, population of bacteria species resident on the selected pre-cut- fruits and vegetables varied and it depended on the type of fruit or vegetable and the market site (Tables 1 and 2). Samples collected from Madina market a suburb of Accra recorded varied population and species of bacteria on Violet Red Bile (VRB) and Plate Count Agar (PCA). Population of bacteria on fruits and vegetables ranged from $\log _{10} 4.37$ to $5.21 \mathrm{cfu} / \mathrm{g}$ on VRB medium and $\log _{10} 4.24$ to $5.08 \mathrm{cfu} / \mathrm{g}$ on PCA. Fruits recorded lower bacteria counts on both media compared to vegetables although this difference was not statistically significant. Among the pre-cut fruits sampled the highest bacteria counts $\left(\log _{10} 4.46 \pm 0.04 \mathrm{cfu} / \mathrm{g}\right)$ was obtained from mango whereas pawpaw recorded the lowest bacteria count $\left(\log _{10} 4.24 \pm 0.23 \mathrm{cfu} / \mathrm{g}\right.$ ) on both media (VRB and PCA). The bacteria count was higher for Okra $\left(\log _{10} 5.21 \mathrm{cfu} / \mathrm{g}\right)$ than cocoyam leaves $\left(\log _{10} 4.69 \pm 0.03 \mathrm{cfu} / \mathrm{g}\right)$. Klebsiella pneumoniae and Staphyloccocus aureus were isolated from all the samples with the exception of okra from which Enterobacter sakazakii was isolated table 1.

Similar trend was recorded for samples collected from Makola market bacteria bacterial counts from fruits ranged from $\log _{10} 4.42$ \pm 0.11 to $4.45 \pm 0.13 \mathrm{cfu} / \mathrm{g}$ and $\log _{10} 4.45 \pm 0.03$ to $\log _{10} 4.49 \pm 0.21$ on VRB and PCA respectively. Staphyloccocus aureus was the most dominant species isolated from all samples with the except from

\begin{tabular}{|c|c|c|c|}
\hline \multirow[t]{2}{*}{$\begin{array}{l}\text { Name of } \\
\text { sample }\end{array}$} & \multicolumn{2}{|c|}{$\begin{array}{l}\text { Total viable enumera- } \\
\text { tion }\left(\log _{10} \mathrm{cfu} / \mathrm{g}\right)\end{array}$} & \multirow{2}{*}{$\begin{array}{c}\text { Bacteria species BA } \\
\text { and Mac. }\end{array}$} \\
\hline & VRB & PCA & \\
\hline Mango & $4.46 \pm 0.04$ & $4.26 \pm 0.03$ & $\begin{array}{l}\text { Staphylococcus aureus } \\
\text { Klebsiella pneumoniae } \\
\text { pneumoniae Coliforms } \\
\text { (able to ferment sugars) }\end{array}$ \\
\hline Pawpaw & $4.37 \pm 0.23$ & $4.24 \pm 0.12$ & $\begin{array}{l}\text { K. pneumoniae pneu- } \\
\text { moniae, Staphylococcus } \\
\text { aureus } \\
\text { Coliforms (Gram -ve } \\
\text { rods) }\end{array}$ \\
\hline Okra & $5.21 \pm 0.06$ & $5.05 \pm 0.08$ & Enterobacter sakazakii \\
\hline Cocoyam & $4.69 \pm 0.03$ & $5.08 \pm 0.07$ & $\begin{array}{c}\text { Chryseomonas luteola, } \\
\text { Staphylococcus aureus, E. } \\
\text { sakazakii, K. pneumonia } \\
\text { pneumoniae }\end{array}$ \\
\hline
\end{tabular}

Table 1: Enumeration and occurrence of bacteria in selected precuts fruits and vegetables from Madina market a suburb of Accra.

Key: ** Average of 3 plates x 3 different sampling periods $\log _{10} \mathrm{cfu} / \mathrm{g}$ indicate population of bacteria isolated on Violet Red Bile (VRB) and Plate Count Agar (PCA) whereas diversity of bacteria species was isolated on Blood Agar Base (BA) and Ma Conkey (Mac.) media respectively.

\begin{tabular}{|c|c|c|c|}
\hline \multirow[t]{2}{*}{$\begin{array}{l}\text { Name of } \\
\text { sample }\end{array}$} & \multicolumn{2}{|c|}{$\begin{array}{l}\text { Total viable count } \\
\left(\log _{10} \mathrm{cfu} / \mathrm{g}\right)\end{array}$} & \multirow[t]{2}{*}{$\begin{array}{c}\text { Bacteria species BA and } \\
\text { Mac. }\end{array}$} \\
\hline & VRB & PCA & \\
\hline Mango & $4.45 \pm 0.13$ & $4.45 \pm 0.03$ & $\begin{array}{c}\text { Coliforms (able to ferment } \\
\text { sugar), Staphylococcus } \\
\text { aureus }\end{array}$ \\
\hline Pawpaw & $4.42 \pm 0.11$ & $4.49 \pm 0.21$ & $\begin{array}{c}\text { Coliforms (able to ferment } \\
\text { sugar) Staphylococcus } \\
\text { aureus }\end{array}$ \\
\hline Okra & $5.41 \pm 0.02$ & $5.39 \pm 0.09$ & $\begin{array}{c}\text { Coliforms (Gram -ve rods } \\
\text { unable to ferment sugars) } \\
\text { Klebsiella pneumoniae, } \\
\text { Staphylococcus aureus }\end{array}$ \\
\hline Cocoyam & $5.10 \pm 0.10$ & $5.29 \pm 0.11$ & $\begin{array}{c}\text { Enterobacter cloacae, } \\
\text { Coliforms (Gram -ve rods } \\
\text { unable and able to fer- } \\
\text { ment sugars) }\end{array}$ \\
\hline
\end{tabular}

Table 2: Estimation of bacteria population and occurrence in selected pre-cut fruits and vegetables sampled from Makola market a suburb of Accra.

Key: ** Average of 3 plates $x 3$ different sampling periods $\log _{10} \mathrm{cfu} / \mathrm{g}$ indicate population of bacteria isolated on Violet Red Bile (VRB) and Plate Count Agar (PCA) whereas diversity of bacteria species were isolated on Blood Agar Base (BA) and MaConkey (Mac.) media respectively. 
cocoyam leaves. Klebsiella pneumoniae and Enterobacter sakazakii were isolated from Okra and cocoyam leaves respectively. there were Although not statistically significant, the bacteria count for pre-cut vegetables was higher than for pre-cut fruits (Table 2).

Mycofloral population and diversity of fungal species isolated from indicated pre-cut- fruits and vegetables sampled from Madina and Makola markets on either cooke's medium or dichloran rose Bengal chloramphenicol (DRBC)

Similarly, the population of fungi resident on mango, pawpaw, cocoyam leaves and okra also varied from $\log _{10} 3.60 \mathrm{cfu} / \mathrm{g}$ to $\log _{10}$ $4.64 \mathrm{cfu} / \mathrm{g}$ depending on the sample. There was no statistical difference $(p \geq 0.05)$ between populations of fungi resident on precuts- fruits and vegetables on both media. For example, with the exception of cocoyam leaves which recorded a higher numerical value of $\log _{10} 4.64 \mathrm{cfu} / \mathrm{g}$ as compared with pawpaw which recorded the lowest numerical value of $\log _{10} 3.60 \mathrm{cfu} / \mathrm{g}$; fungal population obtained for all the remaining samples had a difference of less than one log cycle (Table 3). Species diversity also varied depending on the market site, medium and sample used for isolation. A total of 14 different species belonging to nine (9) genera were isolated at Madina market. Eight (8) species were recorded on mango and cocoyam leaves whereas pawpaw and okra had six (6) and seven (7) species respectively. The 9 genera included, Aspergillus, Cladosporium, Fusarium, Mycelia sterilia, Penicillium, Rhizopus, Rhodotorula, Streptomyces and Yeast species. The most dominant species was Rhodotorula, followed by Yeast spp., Aspergillus species (. i.e. A. fumigatus, A. flavus, A. niger, A. terreus), Fusarium, Streptomyces sp., Mycelia sterilia, Penicillium, Cladosporium, and Rhizopus. There was no statistical difference ( $\mathrm{p} \geq 0.05$ ) between the average fungal population recorded on pre-cut- fruits and vegetables although numerically the highest was obtained on okra $\left(\log _{10} 4.36 \mathrm{cfu} / \mathrm{g}\right)$ whereas the lowest $\left(\log _{10} 3.98 \mathrm{cfu} / \mathrm{g}\right)$ was recorded on pawpaw. The following species Aspergillus flavus, A. fumigatus, and Yeast spp. were isolated from all the samples whereas A. niger was obtained on all the samples with the exception of cocoyam leaves whereas species such as A. terreus, Cladosporium herbarum, Fusarium oxysporum, F. poae, Myceilia sterilia, Penicillium digitatum, P. expansum, and Rhizopus stolonifer were isolated on specific precut- fruits and vegetables. For examples, A. terreus, C. herbarum, F. poae and F. oxysporum and P. digitatum were only isolated from cocoyam leaves whereas Mycelia sterilia was only isolated on okra.
On the other hand, Rhizopus stolonifer was recorded on pawpaw and okra while P. expansum and Streptomyces sp. were only isolated from mango (Table 3 and 5).

Likewise, there was no statistical difference $(p \geq 0.05)$ between the average fungal population recorded on pre-cut- fruits and vegetables isolated from Makola samples although numerically they differ. The trend was similar to data obtained for samples collected from the Madina market for example, the highest fungal population recorded was obtained on okra $\left(\log _{10} 5.09 \mathrm{cfu} / \mathrm{g}\right)$ whereas the lowest $\left(\log _{10} 4.46 \mathrm{cfu} / \mathrm{g}\right)$ was recorded on pawpaw (Table 4). The most frequent species is Rhodotorula followed by Yeast and Streptomyces species, Aspergillus species (especially A. flavus) and Mycelia sterilia. These species were isolated from all the samples whereas the

\begin{tabular}{|c|c|c|c|}
\hline \multirow{2}{*}{$\begin{array}{l}\text { Name of } \\
\text { sample }\end{array}$} & \multicolumn{2}{|c|}{ Medium for isolation } & \multirow{2}{*}{$\begin{array}{c}\text { Name of fungal species } \\
\text { isolated }\end{array}$} \\
\hline & Cooke's & DRBC & \\
\hline & \multicolumn{3}{|c|}{ Fungal population $\left(\log _{10} \mathrm{cfu} / \mathrm{g}\right) \pm \mathrm{SE}$} \\
\hline Mango & $3.99 \pm 0.18$ & $4.31 \pm 0.64$ & $\begin{array}{c}\text { Aspergillus flavusA. fu- } \\
\text { migatus, Aspergillus niger, } \\
\text { Penicillium expansum } \\
\text { Rhizopus stolonifer Rho- } \\
\text { dotorula sp. Streptomyces } \\
\text { sp., Yeast sp. }\end{array}$ \\
\hline Pawpaw & $3.60 \pm 0.17$ & $4.36 \pm 0.92$ & $\begin{array}{l}\text { A. flavus, A. fumigatus, } A \text {. } \\
\text { niger, Rhizopus stolonifer, } \\
\text { Rhodotorula sp., Yeast sp. }\end{array}$ \\
\hline Okra & $4.28 \pm 0.16$ & $4.43 \pm 0.18$ & $\begin{array}{l}\text { A. flavus, A. fumigatus, } \\
\text { A. niger, Mycelia sterilia, } \\
\text { Rhizopus stolonifer, Rho- } \\
\text { dotorula sp., Yeast sp., }\end{array}$ \\
\hline $\begin{array}{l}\text { Cocoyam } \\
\text { leaves }\end{array}$ & $3.70 \pm 0.26$ & $4.64 \pm 0.14$ & $\begin{array}{c}\text { A. flavus, A. fumigatus, } \\
\text { A. terreus, Cladosporium } \\
\text { herbarum, Fusarium oxys- } \\
\text { porum F. poae, Penicillium } \\
\text { digitatum, Rhodotorula } \\
\text { sp, Yeast sp. }\end{array}$ \\
\hline
\end{tabular}

Table 3: Mycoflora population and species diversities isolated on fresh pre-cut fruits and vegetables sampled from Madina market on Cooke's and DRBC media.

**Average of 3 plates x 3 different sampling periods $\log _{10} \mathrm{cfu} / \mathrm{g}$ indicate population of fungi isolated on Cooke's and DRBC media respectively. 
remaining species were isolated on specific samples. For examples, Fusarium oxysporum and $A$. fumigatus were isolated from all the samples except okra while $A$. parasiticus was recorded on only vegetable samples. In another instances, species such as Geotrichum candidum and P. glabrum were only isolated from okra whereas $A$. candidus and $C$. herbarum were also obtained on cocoyam leaves only. Pre-cut pawpaw sample recorded two species $A$. wentii and $P$. verrucosum which were not recorded by any other samples (Table 4).

\begin{tabular}{|c|c|c|c|}
\hline \multirow[t]{2}{*}{$\begin{array}{l}\text { Name of } \\
\text { sample }\end{array}$} & \multicolumn{2}{|c|}{$\begin{array}{l}\text { Medium for isolation } \\
\text { Cooke's DRBC }\end{array}$} & $\begin{array}{c}\text { Name of fungal species } \\
\text { isolated }\end{array}$ \\
\hline & \multicolumn{3}{|c|}{ Fungal population $\left(\log _{10} \mathrm{cfu} / \mathrm{g}\right) \pm \mathrm{SE}$} \\
\hline Mango & $4.61 \pm 0.13$ & $4.45 \pm 0.42$ & $\begin{array}{c}\text { Aspergillus flavus A. } \\
\text { fumigatus, A. niger, A. } \\
\text { terreus, Fusarium oxys- } \\
\text { porum } \\
\text { Mycelia sterilia Rhizopus } \\
\text { oryzae Rhodotorula sp. } \\
\text { Streptomyces sp., Yeast } \\
\text { sp. }\end{array}$ \\
\hline Pawpaw & $4.38 \pm 0.33$ & $4.54 \pm 0.30$ & $\begin{array}{c}\text { A. flavus, A. fumigatus, } \\
\text { A. wentii, F. oxysporum, } \\
\text { Penicillium verrucosum, } \\
\text { Rhizopus stolonifer, Rho- } \\
\text { dotorula sp., Streptomy- } \\
\text { ces sp., Yeast sp. }\end{array}$ \\
\hline Okra & $5.12 \pm 0.15$ & $5.05 \pm 0.05$ & $\begin{array}{l}\text { A. flavus, A. parasiticus, } \\
\text { Geotrichum candidum, } \\
\text { Mycelia sterilia, Penicil- } \\
\text { lium glabrum, } \\
\text { Rhodotorula sp., Strepto- } \\
\text { myces sp. Yeast sp., }\end{array}$ \\
\hline $\begin{array}{l}\text { Cocoyam } \\
\text { leaves }\end{array}$ & $4.76 \pm 0.16$ & $4.88 \pm 0.35$ & $\begin{array}{l}\text { A. candidus, A. flavus, } A \text {. } \\
\text { fumigatus, A. parasiticus, } \\
\text { Cladosporium herbarum, } \\
\text { Fusarium oxysporum, } \\
\text { Mycelia sterilia, Rhodo- } \\
\text { torula sp., Streptomyces } \\
\text { sp., Yeast sp. }\end{array}$ \\
\hline
\end{tabular}

Table 4: Mycoflora population and species diversities isolated on fresh pre-cut fruits and vegetables sampled from Makola market on Cooke's and DRBC media.

**Average of 3 plates x 3 different sampling periods $\log _{10} \mathrm{cfu} / \mathrm{g}$ indicate population of fungi isolated on Cooke's and DRBC media respectively.

\begin{tabular}{|l|c|c|}
\hline Madina Market & $\begin{array}{c}\text { Name of market samples } \\
\text { were collected }\end{array}$ \\
\hline Fungal species & Madina & Makola \\
\hline Aspergillus candidus & + & - \\
\hline A. fumigatus & + & + \\
\hline A. flavus & + & + \\
\hline A. glaucus & - & + \\
\hline A. niger & + & - \\
\hline A. nidulans & - & + \\
\hline A. ustus & + & + \\
\hline Candida tropicalis & + & + \\
\hline Cladosporium herbarum & - & + \\
\hline Fusarium oxysporum & + & - \\
\hline F. poae & + & - \\
\hline Gliocladium roseum & + & + \\
\hline Penicillium funiculosum & - & + \\
\hline Rhodotorula mucilginosa & - & + \\
\hline
\end{tabular}

Table 5: Occurrence of aeromicroflora in the two markets (Madina and Makola) isolated on Cooke's and DRBC media.

Key: Presence (+) Absence (-)

Clearly, data reported in this study demonstrated that fungal population and species diversity depended on the market site, sample and the medium used for isolation.

\section{Analysis of aeromicroflora of the two market sites}

The microflora of any habitat varies with environmental condition, host type and relation among them. Fourteen (14) air-borne fungi were isolated belonging to seven (7) genera Aspergillus, Candida, Cladosporium, Fusarium, Gliocladium, Penicillium and Rhodotorula. The most dominant species was Aspergillus recording 7 different species followed by Fusarium, 2 species and the other genera recorded a species each. Madina market recorded nine (9) aeromycoflora whereas Makola market had ten (10) air-borne fungi. Species such as Aspergillus flavus, A. fumigatus, A, ustus, Candida tropicalis and Gliocladium roseum occurred at both markets whereas species such $A$. candidus, A. niger, Fusarium oxysporum and $F$. poae were recorded only for Madina market. Species such as Aspergillus glaucus, A. nidulans, Cladosporium herbarum and Penicillium funiculosum, Rhodotorula mucilginosa were obtained from Makola market (7). No growth was recorded for bacteria at both markets (Table 5). 


\section{Discussion}

Consumption of fruit and vegetable has dramatically increased in both developed and developing countries such the United States, India, Nigeria to mention but a few by more than $30 \%$ during the past few decades. The story of consumption of pre-cut fruits and vegetables has also become a daily habit mostly by majority of city dwellers in Ghana [12]. Scientists recommend that everyone eat five to nine servings of fruit and vegetables every day in order to promote good health [4]. The consumption of fresh fruits and vegetables has increased because of important dietary source of nutrients, vitamins and fibre and also play vital roles for health and well-being of human especially for their ability to prevent vitamin C and vitamin A deficiencies; it also reported to reduce the risk of several diseases e.g. cancer and other chronic degenerative diseases such as cardiovascular diseases and diabetes Kalia and Gupta [10]. Due to these health benefits consumers strive to eat healthy diets and benefit from the year-round availability of these products. However, fruits and vegetables normally carry nonpathogenic, epiphytic microflora. During production on the farm and all stages of product handling from harvest to point of sale, produce may be contaminated with microorganisms including human pathogens Beuchat; Beuchat and Ryu [4]. This is because during harvest they have contact with the soil, water during growth, and at storage during handling processing may be in contact with dust as well [13].

This present study provides information on the microbial populations obtained on pre-cut- fruits and vegetables sampled from two major markets in the Accra Metropolis. Data obtained demonstrated that population of microorganisms (bacteria and fungi populations) varied from depending on the sample, market site and medium used for isolation. Bacterial population recorded on all samples collected from Madina market on both Violet Red Bile (VRB) and Plate Count Agar (PCA) varied from $\log _{10} 4.24 \mathrm{cfu} / \mathrm{g}$ to $\log _{10} 5.21 \mathrm{cfu} / \mathrm{g}$. Interestingly, population of bacteria species obtained on samples from Makola market recorded similar microbial load of $\log _{10} 4.42 \mathrm{cfu} / \mathrm{g}$ and $\log _{10} 5.41 \mathrm{cfu} / \mathrm{g}$. It was observed that microbial population recorded for the two market areas did not differ significantly although numerically bacteria populations were different for both markets. Average bacteria population recorded for pre-cuts- mango, papaw, okra and cocoyam leaves $\log _{10} 4.36 \pm$ $0.04 \mathrm{cfu} / \mathrm{g}, \log _{10} 4.31 \pm 0.18 \mathrm{cfu} / \mathrm{g}, \log _{10} 5.13 \pm 0.07 \mathrm{cfu} / \mathrm{g}$, and $\log _{10}$
$4.89 \pm 0.05 \mathrm{cfu} / \mathrm{g}$ respectively. The case at Makola market was not different, the population of bacteria species was approximately the same as that recorded for the Madina market. Mean microbial load obtained on pre-cut- mango, pawpaw, okra and cocoyam leaves were as follows: $\log _{10} 4.45 \pm 0.02 \mathrm{cfu} / \mathrm{g}, \log _{10} 4.46 \pm 0.16 \mathrm{cfu} / \mathrm{g}, \log _{10}$ $5.40 \pm 0.06 \mathrm{cfu} / \mathrm{g}$, and $\log _{10} 5.20 \pm 0.11 \mathrm{cfu} / \mathrm{g}$ respectively (Tables 1 and 2).

The acceptable limits of microbial quality of most foods is $<5.0$ $\log _{10} \mathrm{cfu} / \mathrm{g}$ for total counts, $<3.0 \log _{10} \mathrm{cfu} / \mathrm{g}$ for Enterobacteriaceae (WHO, 2009); the UK Public Health Laboratory Services requirement ( 6 to $<7$ log cfu/g) [14]. Except for pre-cut- cocoyam leaves and okra the samples recorded bacterial load within the acceptable limits (safe limits). However, some of the samples were beyond the acceptable safe limits of the Ghana Standard Board (GSA) $(<5 \log$ cfu/g) [15]. This was particular true mostly for pre-cut- okra and cocoyam leaves sampled from both markets. Bacteria species isolated on the four samples at the two markets included both Gram positive and negative species. The Gram-negative bacteria belong to the Enterobacteriaceae family and the dominant species was Klebsiella pneumoniae pneumoniae and Enterobacter sakazakii whereas the gram-positive species belong to the Staphylococcaceae with Staphyloccocus aureus as the most predominant species isolated. Other gram-negative bacteria species isolated from the samples included Chryseomonas luteola and Enterobacter cloacae.

The present data confirms other reported findings by Mathur, Joshi and Harwani [5]; Isa., et al. [10]; Jennylynd [4] and Tournas., et al. [16]. Their data showed an array of bacteria and fungi which contaminated fresh fruits and vegetables causing spoilage. Tango., et al. (2014) isolated Staphylococcus aureus, E. coli 0157:H7, Listeria monocytogenes, Bacillus cereus, and Salmonella were isolated on leafy vegetables at different areas in Korea. In Nigeria Adeleke., et al. [17] investigated public health risks associated with apples and carrots sold in major markets and recorded seven species Pseudomonas aeruginosa, Staphylococcus aeureus, Enterococcus faecalis, Bacillius cereus, Listeri monocytogenes, Citrobacter species, and Candida species; and two parasitic organisms, cysts of Entamoeba coli and ova of Ascaris lumbricoides were isolated from the fruits. Viswanathan and Kaur [5] also examined different salad vegetables such as carrots, radishes, tomatoes, lettuce, cabbage, cucumbers, coriander and reported the presence of S. aureus, E. coli, Entero- 
bacter spp., Klebsiella spp., S. typhi, Serratia spp., Providencia spp. and P. aeruginosa. The presence of Chryseomonas luteola (fr. Pseudomonas luteola), Enterobacter cloacae, E. sakazakii, Klebsiella pneumoniae pneumoniae and Staphyloccocus aureus recorded in this present study have been associated with publicized fresh produce foodborne outbreaks of public health significance [4]. For example, C. luteola might cause septicemia, meningitis, leg ulcer, discitis, endocarditis and peritonitis. E. cloacae have taken on clinical significance as opportunistic bacteria and have emerged as nosocomial pathogens from intensive care patients pathogenic, especially to those who are on mechanical ventilation Mezzatesta., et al. [18]. Enterobacter sakazakii (Cronobacter spp.) is a pathogen that generally causes disease only in people with weakened immune systems and can cause invasive infections (e.g. sepsis or meningitis) in infant (CFS, 2014). Klebsiella pneumoniae subsp. pneumoniae (Kpp) is a Gram-negative bacterium within the family Enterobacteriaceae found in the environment and the alimentary tract of animals. Members cause pneumonia and urogenital infections in carnivores and ungulates, mastitis in ruminants and pigs, enterocolitis in rabbits and sporadic septicaemia in a number of species [19]. Wu., et al. [20] reported that immunosuppressed individuals, patients affected by diabetes mellitus, or intravenous drug abusers, K. pneumoniae can induced multiple infections may arise from gastrointestinal disease following bacterial translocation from the intestine to the portal circulation. Staphylococcus aureus is commonly present in human nasal passage, throat, hair and skin without causing any discomfort their presence in ready to eat fruits and vegetables may cause gastroenteritis due to production of enterotoxins by the bacteria and sometimes may even cause the spoilage of the fruits and vegetables when their population is high. Documentation of $S$. aureus in this present study was not a coincidence because foods that require considerable handling during preparation, particularly with bare hands, and that are kept at elevated temperatures after preparation are often involved in staphylococcal food poisoning (CFS, 2014). Due to this, if fruits are and vegetables are cut and handled with bare hands, S. aureus may be present on the sliced products and could produce several enterotoxins that are responsible for food poisoning. The health hazards on human makes it imperative to assess the microbial load on pre-cut fruits and vegetables to safeguard the health of consumers although the recorded population of bacteria was below the same limit of WHO.
Similarly, there was variation in diversity and the population of resident mycoflora recorded in this study. The general trend was that the variation was dependent on the sample, market site and the medium use for isolation. A total of twenty-one (21) species were resident in the four samples belonging to ten (10) genera (i.e. Aspergillus, Cladosporium, Fusarium, Geotrichum, Mycelia sterilia, Penicillium, Rhizopus, Rhodotorula, Streptomyces and Yeast spp.) (Tables 3 and 4). Population of fungi on the samples ranged from $\log _{10} 3.70 \pm 0.26 \mathrm{cfu} / \mathrm{g}$ to $\log _{10} 4.64 \pm 0.14 \mathrm{cfu} / \mathrm{g}$ for Madina market while samples collected from Makola market recorded populations between $\log _{10} 4.38 \pm 0.33 \mathrm{cfu} / \mathrm{g}$ to $\log _{10} 5.12 \pm 0.15 \mathrm{cfu} / \mathrm{g}$. The most frequent species was Rhodotorula mucilginosa followed by Yeast and Streptomyces species, Aspergillus species (especially A. flavus) and Mycelia sterilia. The acceptable limits of microbial quality of most foods is $<5.0 \log _{10} \mathrm{cfu} / \mathrm{g}$ for total counts, $<3.0 \log _{10} \mathrm{cfu} / \mathrm{g}$ for Enterobacteriaceae. Mycoflora population resident on the studied samples was all within the same limit of $<5.0 \log _{10}$ cfu/g for total counts with the exception okra sampled from Makola market which recorded fungal population as high as $\log _{10} 5.12 \pm 015 \mathrm{cfu} / \mathrm{g}$ and $\log _{10} 5.05 \pm 0.05 \mathrm{cfu} / \mathrm{g}$ (Table 4). Although the population of resident fungi of all samples with the exception of okra were below the safe limits there were some species of pathological importance such species included Aspergillus candidus, A. flavus, A. niger, A. parasiticus, A. terreus, Fusarium oxysporum, F. poae, Penicillium expansum and $P$. verrucosum. This is because the majority of mycotoxins of greatest concern to human and animal health are produced by the genera belonging to Aspergillus, Penicillium, and Fusarium Reddy and others (as cited in Samina, 2015). Currently more than 400 mycotoxins are known out of which the most important ones with pathological impact concerning human and animal health and economic impact are aflatoxins, ochratoxin A (OTA), feminizing, zearalenone (ZEA), deoxynivalenol (DON), and patulin (Odamtten., et al., 2018; Samina, 2015). Although, analysis of mycotoxins present in the samples was not carried out the preponderance of Aspergillus, Fusarium and Penicillium species particularly, A. candidus (candidulin, terphenyllin, xanthoascin), A. flavus (aflatoxin B1, B2, G1, G2), A. fumigatus (gliotoxin, fumigalin), A. niger (ochratoxin A, patulin), A. parasiticus (aflatoxin B1, B2, G1, G2, sterigmatocyctin), A. terreus (territrems, citrinin, citreoviridin), Fusarium poae (deoxynivalenol/nivalenol, trichothecenes A), F. oxysporum (enniatins, HT-2 toxin, fumonisins, moniliformin, zearalenone), Penicillium expansum 
(patulin, citrinin) and P. verrucosum (ochratoxin A, patulin) [2125]. The health implications of consuming these fruits and vegetables contaminated with any of these species for example aflatoxins are immunosuppressive, mutagenic, teratogenic and carcinogenic in their effect with the main target organ being the liver Peraica., et al. (as cited Odamtten., et al., 2018). Evaluation of epidemiological and laboratory analysis by International Agency for Research in Cancer (IARC) showed that there is sufficient evidence in humans for carcinogenicity of naturally occurring aflatoxins. Ochratoxins A $(\mathrm{OA})$ are nephrotoxins and based on the carcinogenicity of $\mathrm{OA}$, the World Health Organization proposed a maximum limit for OA of 5 $\mathrm{mg} / \mathrm{kg}$ in cereals [25]. Acute renal failure in one person, possibly caused by inhalation of ochratoxin A in a granary which had been closed for 2 years, was reported in Italy Paolo., et al. [26,27].

Bacterial and fungal diversity recorded in this study corroborated with other several previous reports by Amoah [28]; Isa., et al. [10]; Manthur., et al. [5]; Tango., et al. 2014; Eni., et al. [29], Tournas [13] who documented similar bacteria and fungi species on apple, mango, pawpaw, cucumber, carrot, onion, tomato, pineapple, lettuce etc. These researchers provided bacteria species such as Escherichia coli, Staphylococcus aureus, Streptoccocus, Klebsiella, Pseudomonas spp., Listeria monocytogenes, Salmonella spp., Actinomycetes etc. while reported species of fungi such as Aspergillus flavus, A. fumigatus, Fusarium solani, F. oxysporium, Geotrichum spp., Rhizopus stolonifer, Mucor piriformis, Penicillium funiculosum, P. expansum, P. digitatum etc were reported to have contaminated fruits and vegetables.

To ascertain the source of these contaminants recorded in this study aero microflora sampling was carried out at the market sites where the various samples were bought. Fourteen (14) air-borne fungi were isolated belonging to seven (7) genera $A s$ pergillus, Candida, Cladosporium, Fusarium, Gliocladium, Penicillium and Rhodotorula (Table). Data obtained indicated that species such as A. candidus, A. flavus, A. fumigatus, A. niger, C. herbarum, Fusarium oxysprum, F. poae and Rhodotorula mucilginosa were already present in the environment which found its way to contaminate pre-cut- fruits and vegetables sold at these two markets. The Other species such as Aspergillus parasiticus, A. terreus, A. wentii, Geotrichum candidum, Mycelia sterilia, Penicillium glabrum, P. expansum, P. verrucosum, Rhizopus stolonifer, Streptomyces, and Yeast spp. were isolated from the samples (i.e. pre-cut- mango, pawpaw, okra and cocoyam leaves) might have contaminated the samples through the vendor or were already present in the fruits and vegetables. This is because Good Hygienic Practice (GHP) as defined in the Codex document on "General Principles of Food Hygiene" in combination with HACCP is the basis for safe food production (Codex Alimentarius, 1997). There are several potential hazards in the food chain, and these include contamination during production, in the field at harvest, post-handling, storage and distribution, and consumer handling. It is therefore evident that one cannot easily tell the point of contamination and the only way to curtailed potential hazards is to ensure good hygiene practices in combination with Hazard Analysis and Critical Control Point (HACCP) [30-32].

\section{Conclusion}

The study provided bacterial and fungal contaminants in freshcut fruits and vegetables sampled from two major market sites Madina and Makola-Accra Ghana. Although microbial populations were within the WHO safe limits except for okra and cocoyam leaves samples there are still concerns to address the contamination of these species in our foods. For example, the group members of Enterobacteriaceae are widely known for intestinal infection and diarrhea; fungi although they are commonly not associated with food poisoning but if turned out to be poisonous, it can cause hallucination, nausea, vomiting, abdominal pain and diarrhea. In addition, some mycotoxins produced by such fungi as indicated above may cause cancer of the liver or kidney. To avert these potential hazards on fruits and vegetables strict good hygienic practice in combination with HACCP should be adhered to at all levels.

\section{Acknowledgement}

We thank Mrs. Vida Yirenkyiwaa of Noguchi Memorial Institute of Medical Research and Mr. George Akwetey at the Department of Plant and Environmental Biology for their technical support.

\section{Bibliography}

1. International Agency for Research on Cancer (IARC) Handbooks of Cancer Prevention, Fruit and Vegetables. H.J. Vainio and F. Bianchini 6.8 (2003): 300.

2. Buyukunal S., et al. "Microbiological Quality of Fresh Vegetables and Fruits Collected from Supermarkets in Istanbul, Turkey". Journal of Food and Nutrition Sciences 3 (2015):152-159. 
3. Obeta SE., et al. "Microbial effect of selected stored fruits and vegetables under ambient conditions in Markudi, Benue State, Nigeria". Research Journal of Applied Sciences, Engineering and Technology (2011).

4. Jennylynd J. Overview of Microbial Hazards in Fresh Fruit and Vegetables Operations John Wiley and Sons, Inc (2006).

5. Mathur A., et al. "Microbial Contamination of Raw Fruits and Vegetables”. Internet Journal of Food Safety 16 (2014): 26-28.

6. WHO (World Health Organization). Background paper: developing a food safety strategy (WHO strategic planning meeting) (2001).

7. GNA (Ghana News Agency). Producing unsafe food is unwise (2010).

8. Barth M., et al. "Microbiological Spoilage of Fruits and Vegetables". (W. Sperber, and M. Doyle, Eds.) (2009): 135-138.

9. Centre for food safety Microbiological quality of Pre-cut fruits for sale or serving in retail outlets (2006).

10. Isa A., et al. "Bacteriological Quality of Fruits and Vegetables Sold at Maiduguri Metropolis". Nigeria 3.2 (2014).

11. Odamtten GT., et al. "Resident microbial load, toxigenic potential and possible quality control measures of six imported seasoning powders on the Ghanaian market". Journal of Nutritional Health and Food Engineering 8.1 (2018): 1-11.

12. Amoah D. "Microbial Risk Assessment of Mixed Vegetables Salads from Selected Canteens In the Kumasi Metropolis". Kumasi (2014).

13. Tournas V. "Moulds and yeasts in fresh and minimally processed vegetables and sprout". International Journal of Food Microbiology 99.1 (2005): 71-77.

14. Public Health Laboratory Service (PHLS). "Guidelines for the microbiological quality of some ready-to-eat foods sampled at the point of sale". Communicable Disease and Public Health 3 (2002): 163-167.

15. GSB (Ghana Standards Board), Local reference standards, GS 7006 (2003): 1-44.
16. Tournas V., et al. "Moulds and yeast in fruit salads and fruits juice". International Journal of Food Microbiology 23.7 (2006): 684-688.

17. Adeleke MA., et al. "Public health risks associated with apples and carrots sold in major markets in Osogbo". Southwest Nigeria (2012).

18. Regli A and Pagès J-M. "Enterobacter aerogenes and Enterobacter cloacae; versatile bacterial pathogens confronting antibiotic treatment". Frontiers in Microbiology 6 (2015): 392.

19. Bidewell CA., et al. "Emergence of Klebsiella pneumoniae subspecies pneumoniae as a cause of septicaemia in pigs in England". Plos One 13.2 (2018): e0191958.

20. Wu Y., et al. "Klebsiella pneumoniae-Induced Multiple Infections in a Diabetes Mellitus Patient: Pneumonia, Liver Abscess, Endogenous Endophthalmitis, Urinary Tract Infection". (2018).

21. Nogueira M., et al. "Natural contamination with mycotoxins produced by Fusarium graminearum and Fusarium poae in malting barley in Argentina". Toxins 10.2 (2018): E78.

22. Adeyeye SA. "Fungal mycotoxins in foods: A review". Cogent Food and Agriculture 2.1 (2016): 1213127.

23. Ofosu AH., et al. "A study into microbial quality of ready to eat foods sold in the Sunyani Municipality of Ghana". Global Journal Biology Agriculture Health and Sciences 3.3 (2014): 84-91.

24. Hocking AD. Aspergillus and related teleomorphs (2006).

25. Abarca ML., et al. "Current Importance of Ochratoxin A-Producing Aspergillus spp". Journal of food protection 64.6 (2001): 903-906.

26. Paolo Di NP., et al. "Inhaled mycotoxins lead to acute renal failure”. Nephrology, Dialysis, Transplantation 9.4 (1994): 116120.

27. Peraica M., et al. "Toxic effects of mycotoxins in humans". Bulletin of the World Health Organization 77.9 (1999): 754-766.

28. Douglas Amoah. "Microbial risk assessment of mixed vegetable salads from selected canteens in the kumasi metropolis". Department of Biochemistry and Biotechnology, Kwame Nkrumah University of Science and Technology (2014). 
29. Eni AO., et al. "Microbial Quality of Fruits and Vegetables Sold in Sango Ota, Ogun State, Nigeria". African Journal of Food Science, 4.5 (2010): 291-296.

30. Agency GN. Producing unsafe food is unwise (2010) (2017).

31. Beuchat $\mathrm{L}$ and Rhu J. "Produce handling and processing practices”. Emerging Infectious Diseases 3.4 (1997): 459-465.

32. Ismaiel A and Papenbrock J. "Mycotoxins: producing fungi and mechanisms of phytotoxicity". Agriculture 5.3 (2015): 492-537.

Volume 3 Issue 11 November 2019

(C) All rights are reserved by Wiafe-Kwagyan M., et al. 